\title{
KAJIAN YURIDIS UNDANG-UNDANG NOMOR 18 TAHUN 2017 TENTANG PELINDUNGAN PEKERJA MIGRAN INDONESIA
}

\author{
LELISARI $^{1)}$,IMAWANTO ${ }^{2)}$,FAHRURROZ ${ }^{3)}$ \\ Fakultas Hukum Universitas Muhammadiyah Mataram \\ e-mail : ${ }^{1)}$ slelisari@gmail.com, ${ }^{2)}$ imawanto123@gmail.com, ${ }^{3)}$ rozifahrur178@gmail.com
}

\begin{abstract}
ABSTRAK
Sejak disahkannya Undang-Undan No. 18 Tahun 2017 tentang Pelindungan Pekerja Migran Indonesia (UU PPMI), ada istilah baru pengganti Tenaga Kerja Indonesia (untuk selanjunya disebut TKI) menjadi Pekerja Migran Indonesia (untuk selanjutnya disebut PMI). Dengan membaca secara seksama undangundang yang mengatur tentang TKI atau PMI yaitu Undang-Undang Nomor 18 Tahun 2017 tentang PPMI, dibuat untuk memperbaiki berbagai kelemahan yang ada dalam Undang-Undang No 39 tahun 2004, di mana tujuan utama dilakukannya penyempurnaan undang-undang tersebut adalah agar para TKI atau PMI semakin terlindungi. Pada kenyataannya, undang-undang ini juga masih menyimpan beberapa kelemahan. Tujuan penelitian menganalisis kelemahan dalam Undang-Undang No 18 Tahun 2017 tentang PPMI. Metode yang digunakan adalah metode penelitian yuridis normatif dengan pendekatan perundang-undang (statute approach) dan pendekatan konseptual (conceptual approach). Dari hasil penelitian, ada lima kelemahan dalam UU PPMI yaitu: Adanya ketidak konsisten dalam menerapkan aturan, UU PPMI masih menyimpan potensi konflik kelembagaan mengenai kewenangan Kementerian dan Institusi/Badan Non Kementerian dalam tata kelola perlindungan buruh migran, Pasal-pasal di dalam UU PPMI mengenai pembinaan dan pengawasan juga berpotensi sebagai pasal karet karena tidak mengelaborasi mengenai bentuk pembinaan dan pengawasan apa yang seharusnya dilakukan, Belum adanya pasal khusus yang mengafirmasi kebutuhan khusus perlindungan PMI (terutama perempuan) yang bekerja di sektor pekerja rumah tangga, Peraturan mengenai bantuan hukum bagi PMI tidak diatur secara rinci. Sebagai saran segera merevisi UU PPMI, kemudian harus dikawal dan dituntaskan 27 peraturan turunan mandat dari UU PPMI yang terdiri dari 12 Peraturan Pemerintah, 11 Peraturan Menteri, 3 Peraturan Badan dan 1 Peraturan Presiden
\end{abstract}

Kata kunci: Pekerja Migran Indonesia, Perlindungan

\section{ABSTRACT}

Since the enactment of Law No. 18 of 2017 concerning the Protection of Indonesian Migrant Workers (PPMI Law), there is a new term as a substitute for Indonesian Labor (for the next term TKI) to become Indonesian Migrant Workers (hereinafter referred to as PMI). By carefully reading the law governing TKI or PMI, namely Law Number 18 of 2017 concerning PPMI, it is made to correct various weaknesses in Law No. 39 of 2004, in which the main objective is to improve the law. thus TKI or PMI are increasingly protected. In fact, this law also still has some weaknesses. The research objective is to analyze weaknesses in Law No. 18 of 2017 concerning PPMI. The method used is a normative juridical research method with a statute approach and a conceptual approach. From the results of the study, there are five weaknesses in the PPMI Law, namely: There is inconsistency in implementing the rules, the PPMI Law still holds potential institutional conflicts regarding the authority of Ministries and Institutions / Non-Ministerial Bodies in the management of migrant workers protection, Articles in the PPMI Law concerning coaching and supervision also has the potential to be a rubber article because it does not elaborate on what forms of supervision and supervision should be carried out. There is no specific article that affirms the specific needs of PMI protection (especially women) who work in the domestic sector. Regulations regarding legal assistance for PMI are not regulated in detail. As a suggestion to immediately revise the PPMI Law, then it must be guarded and completed 27 regulations derived from the mandate of the PPMI Law consisting of 12 Government Regulations, 11 Ministerial Regulations, 3 Agency Regulations and 1 Presidential Regulation 


\section{PENDAHULUAN}

Dewan Perwakilan Rakyat Republik Indonesia (DPR-RI) telah secara resmi mengesahkan rancangan undang-undang (RUU) Pelindungan Pekerja Migran Indonesia menjadi Undang-Undang Pelindungan Pekerja Migran Indonesia untuk menggantikan Undang-Undang No. 39 Tahun 2004 tentang Penempatan dan Perlindungan Tenaga Kerja Indonesia di Luar Negeri. Pengesahan ini menandakan akhir dari perjalanan panjang yang lamban dan terjal dari proses legislasi untuk perlindungan buruh migran Indonesia yang setiap saat menghadapi kerentanan, mulai dari soal pengupahan, pengusiran, penganiayaan, pelecehan seksual, perkosaan bahkan hukuman mati.

Sejak disahkannya Undang-Undang No 18 Tahun 2017 tentang Pelindungan Pekerja Migran Indonesia, ada istilah baru pengganti Tenaga Kerja Indonesia (TKI) menjadi Pekerja Migran Indonesia (untuk selanjutnya disebut PMI).

Ada beberapa catatan bisa dituliskan terkait dengan kelambanan proses legislasi ini. Dari sisi proses, pembahasan yang sangat lamban ini masih memperlihatkan bahwa persoalan buruh migran Indonesia belum dianggap prioritas sehingga tidak ada political will untuk menuntaskan proses legislasi ini. Proses yang lamban ini mengakibatkan adanya kemandekan inisiatif-inisiatif perlindungan buruh migran oleh pemerintah pusat dan pemerintah daerah dengan dalih bahwa tidak boleh ada kreasi kebijakan yang tidak berdasar pada UU No.39 tahun 2004 tentang Penempatan dan Perlindungan Tenaga Kerja Indonesia Di Luar Negeri.

Dengan membaca secara seksama undang-undang yang mengatur tentang TKI atau PMI yaitu UndangUndang Nomor 18 Tahun 2017 tentang Pelindungan Pekerja Migran Indonesia (untuk selanjutnya disebut UU PPMI), dibuat untuk memperbaiki berbagai kelemahan yang ada dalam Undang-Undang No 39 tahun 2004, di mana tujuan utama dilakukannya penyempurnaan undang-undang tersebut adalah agar para TKI atau PMI semakin terlindungi sebagaimana diamanatkan dalam UUD 1945.

Semangat dari Undang-Undang No 18 tahun 2017 sebagaimana dituangkan dalam penjelasan umum adalah agar PMI terlindungi dari perdagangan manusia, termasuk perbudakan dan kerja paksa, korban kekerasan, kesewenang-wenangan, kejahatan atas harkat dan martabat manusia, serta perlakuan lain yang melanggar hak asasi manusia. Selain itu, undang-undang tersebut lebih menekankan dan memberikan peran yang lebih besar kepada pemerintah dan mengurangi peran swasta dalam penempatan dan Perlindungan Pekerja Migran Indonesia.

Dalam undang-undang No 18 tahun 2017 ini, sudah ada regulasi yang lebih baik dan dapat menjadikan patokan untuk menjadikan TKI/PMI kita lebih memiliki nilai bargaining position yang jelas sesuai dengan skill dan kompetensi yang dimiliki oleh masing-masing TKI/PMI. Seharusnya dengan disahkannya undang-undang baru tentang perlindungan pekerja migran ini, maka para pekerja migran kita lebih percaya diri dalam hal memperjuangkan hak-haknya, meskipun mereka bekerja hanya sebagai pembantu rumah tangga atau asisten rumah tangga (Hani Adhani, dalam https://www.hukumonline.com/berita/baca/lt5acaed204a40c /melindungi-pekerja-migran-indonesia-oleh-hani-adhani, diakses pada tanggal 1 Maret 2019)

Hal lain yang patut mendapat apresiasi adalah adanya perubahan-perubahan yang signifikan dalam undang-undang ini terkait tata kelola migrasi tenaga kerja terutama dengan adanya penguatan peran negara, tidak hanya di tingkat pusat, tetapi juga pengakuan yang signifikan atas peran pemerintah di tingkat daerah (mulai propinsi, kabupaten/kota hingga tingkat desa). Hal ini memperlihatkan adanya komitmen untuk menghadirkan negara (di semua tingkatan) dalam memberikan perlindungan pada buruh migran, mengakhiri proses sentralisasi tata kelola migrasi tenaga kerja yang eksploitatif serta mendorong tanggung jawab dan rasa kepemilikan (ownership) dari pemerintah daerah mengenai perlindungan buruh migran Indonesia. Undang-Undang ini mengamanatkan bahwa tidak boleh ada pembebanan biaya penempatan terhadap buruh migran Indonesia. Amanat ini harus benar-benar terwujud dalam implementasi kebijakan dan tidak boleh disabotase pada peraturan-peraturan pelaksananya (Wahyu Sosilo, dalam https://www.dw.com/id/membacakritis-uu-pelindungan-pekerja-migran-indonesia/a-41595460, diakses pada Tanggal 1 Maret 2019)

Dari uraian latar belakang di atas, maka yang menjadi permasalahan adalah apa saja kelemahankelemahan yang ada dalam Undang-Undang No 18 Tahun 2017 tentang Pelindungan Pekerja Migran Indonesia.

Adapun yang menjadi tujuan dalam tulisan ini adalah untuk mengetahui dan menganalisis tentang kelemahan-kelemahan yang ada dalam Undang-Undang No 18 Tahun 2017 tentang Pelindungan Pekerja Migran Indonesia. Manfaat dari tulisan ini adalah memberikan informasi dan masukan kepada pembuat undang-undang, pemerintah dan pejabat terkait mengenai perlindungan pekerja migrant Indonesia. 


\section{METODE PENELITIAN}

\section{Jenis Penelitian}

Jenis penelitian hukum dalam penelitian ini adalah: Penelitian hukum yuridis normatif berdasarkan pertimbangan bahwa penelitian ini berangkat dari analisis peraturan perundang-udangan yang menjelaskan tentang aspek-aspek hukum yang terkait dengan Pelindungan Terhadap Pekerja Migran Indonesia. Penelitian ini akan dilakukan dengan cara meneliti bahan hukum primer, bahan hukum sekunder serta bahan hukum tersier.

\section{Metode Pendekatan}

Dalam penelitian yang agar memenuhi kriteria ilmiah dan dapat mendekati kebenaran, maka metode pendekatan yang digunakan adalah :

a. Pendekatan perundang-undangan (statuta approach)

Pendekatan perundang-undangan merupakan pendekatan yang mengkaji tentang asas-asas hukum, norma-norma hukum, dan peraturan perundang-undangan. yaitu Undang-undang Dasar Negara republik Indonesia 1945, Undang-undang Nomor 18 Tahun 2017 tentang Pelindungan Terhadap Pekerja Migran Indonesia dan peraturan perundang-undangan lainnya yang terkait dengan penelitian ini.

b. Pendekatan konsep (conceptual approach)

Pendekatan konsep adalah pendekatan yang dilakukan dengan mengkaji literatur-literatur yang ada kaitannya dengan permasalahan yang dikaji dalam penelitian ini.

\section{Sumber dan Jenis Bahan Hukum}

Adapun sumber dan jenis bahan hukum yang digunakan dalam penelitia ini adalah:

1) Bahan hukum primer adalah bahan-bahan hukum yang mengikat, dan terdiri dari Peraturan perundangundangan yaitu Undang-undang Dasar Negara Republik Indonesia 1945, Undang-undang Nomor 18 tahun 2017 tentang Pelindungan Pekerja Migran Indonesia dan Undang-undang serta peraturan-peraturan lainnya yang terkait dengan penelitian ini.

2) Bahan hukum sekunder adalah bahan yang memberikan penjelasan mengenai bahan hukum primer seperti rancangan Undang-undang, hasil penelitian, atau pendapat pakar hukum. Selain itu bahan hukum sekunder dapat meliputi buku-buku, referensi, makalah, hasil penelitian dan lain-lain yang berkaitan dengan masalah yang diteliti.

3). Bahan hukum tersier adalah bahan yang memberikan petunjuk maupun penjelasan terhadap bahan hukum primer dan bahan hukum sekunder, seperti kamus (hukum), ensiklopedia (Amiruddin \& Zainal Asikin, ,2003:119),

\section{Teknik Pengumpulan Bahan Hukum}

Dalam proses pengumpulan bahan, peneliti menggunakan studi dokumenter, yaitu mengumpulkan bahan-bahan kepustakaan yang berupa Peraturan perundang-undangan, Jurnal, literature dan karya tulis yang berhubungan dengan materi penelitian.

\section{Analisis Bahan Hukum}

Analisa bahan hukum dilakukan secara kualitatif, artinya bahan hukum kepustakaan dianalisis secara mendalam, adapun alasan digunakan metode analisis kualitatif berdasarkan atas pertimbangan; bahan hukum yang dianalisis diperoleh dari berbagai sumber dan sifat dasar bahan hukum yang dianalisis adalah menyeluruh serta memerlukan informasi yang mendalam. Selanjutnya untuk menjawab persoalan dalam penelitian ini, metode atau cara penyimpulan bahan hukum dilakukan dengan cara deduktif yaitu dengan menarik suatu kesimpulan dari data-data yang sifatnya umum ke khusus untuk mendapatkan kejelasan terhadap suatu kebenaran sehingga memperoleh gambaran yang jelas mengenai Kajian yuridis mengenai Undang-Undang No 18 Tahun 2017 Tentang Pelindungan Pekerja Migran Indonesia. 


\section{HASIL DAN PEMBAHASAN}

\section{Kelemahan-kelemahan Undang-Undang Nomor 18 Tahun 2017 Tentang Pelindungan Pekerja Migran Indonesia}

Undang-Undang Pelindungan Pekerja Migran Indonesia (UU PPMI) yang terdiri atas 13 Bab dan 87 Pasal ini dinilai maju karena menggunakan konvensi perlindungan pekerja migran sebagai konsideran utama. Undang-Undang PPMI sebenarnya paralel dengan Undang-Undang Nomor 6 Tahun 2012 tentang Ratifikasi Konvensi Pekerja Migran, akan tetapi masih ada beberapa kelemahan yang menjadi catatan terhadap Undang-Undang Pelindungan Pekerja Migran Indonesia.

Pertama, mengenai dokumen wajib yang dimiliki oleh calon Pekerja migran Indonesia untuk dapat ditempatkan di luar negeri. calon PMI wajib memiliki dokumen sebagai berikut:

a. Surat keterangan status perkawinan, bagi yang telah menikah melampirkan fotokopi buku nikah;

b. surat keterangan izin suami atau istri, izin orang tua, atau izin wali yang diketahui oleh kepala desa atau lurah;

c. sertifikat kompetensi kerja;

d. surat keterangan sehat berdasarkan hasil pemeriksaan kesehatan dan psikologi;

e. paspor yang diterbitkan oleh kantor imigrasi setempat;

f. Visa Kerja;

g. Perjanjian Penempatan Pekerja Migran Indonesia; dan

h. Perjanjian Kerja

Mengenai Pasal 13 huruf g tentang perjanjian penempatan yang menjadi salah satu persyaratan penempatan pekerja migran. Ketentuan Pasal 13 huruf g ini menegaskan bahwa pelaksanaan penempatan pekerja migran hanya melalui perusahaan swasta saja. Padahal dalam undang-undang ini diatur juga tentang penempatan melalui badan dan mandiri, yaitu Pasal 49, menyatakan: pelaksanaan penempatan pekerja migran Indonesia ke luar negeri terdiri atas:

a. Badan

b. Perusahaan Penempatan Pekerja migrant Indonesia; atau

c. Perusahaan yang menempatkan pekerja migran Indonesia untuk kepentingan perusahaan sendiri.

Berdasarkan hal tersebut di atas, terjadi ketidak konsisten dalam menerapkan aturan. Dimana dalam satu sisi disebutkan pelaksanaan penempatan PMI terdiri atas 3 pelaksana yaitu badan, perusahaan swasta dan mandiri, namun di sisi lain terutama tentang perjanjian penempatan PMI yang merupakan salah satu dari dokumen wajib yang dimiliki oleh calon PMI. Dimana mengenai dokumen tersebut hanya melalui perusahaan swasta saja, bagaimana halnya dengan pelaksana penempatan melalui Badan dan mandiri. Hal ini tidak disebutkan, dalam hal ini banyak terjadi penafsiran, seakan-akan hanya perusahaan swasta saja yang dapat melakukan pelaksanaan penempatan pekerja migrant Indonesia.

Undang-Undang ini juga masih membuka celah dari sektor swasta untuk menjalankan bisnis penempatan buruh migran Indonesia bahkan diatur dalam Bab tersendiri. Masih ada belasan pasal yang mengatur rinci mengenai Pelaksana Penempatan Pekerja Migran Indonesia. Sebagaimana undang-undang yang fokusnya (domain hukumnya) pada Perlindungan Buruh Migran, adanya pengaturan rinci mengenai operasional pelaksana penempatan pekerja migran bukan pada tempatnya.

Kedua, Pasal 46 Ayat 2 yang menyebutkan bahwa: kepala Badan yang diangkat oleh Presiden dan bertanggung jawab kepada Presiden melalui Menteri. Pasal ini berpotensi menimbulkan konflik kewenangan antara kementerian dan badan, apabila ingin UU PPMI ini diimplementasikan sebagai instrumen perlindungan, maka harus disosialisasikan kepada seluruh elemen masyarakat. Selain itu, harus dikawal 27 (dua pulu tujuh) peraturan turunan mandat dari UU PPMI ini terdiri dari 12 (dua belas) Peraturan Pemerintah (PP), 11 (sebelas) peraturan setingkat Menteri (Permen), 3 (tiga) peraturan Badan dan 1 (satu) Peraturan Presiden (Perpres). Kemudian melakukan penguatan kepada Pemerintah Daerah. Dimana mendesak Kementerian Keuangan untuk penganggaran layanan terpadu satu atap (LTSA) melalui Dana Alokasi Khusus, serta monitoring dan evaluasi implementasi.

UU PPMI masih menyimpan potensi konflik kelembagaan mengenai kewenangan Kementerian dan Institusi/Badan Non Kementerian dalam tata kelola perlindungan buruh migran. Ini disebabkan masih belum tuntasnya pembahasan mengenai pembagian kerja dan kewenangan kelembagaan. Pasal-pasal yang dihasilkan adalah hasil kompromi, oleh karena itu perlu ada desakan yang kuat kepada Presiden RI untuk bisa menuntaskannya dalam penerbitan peraturan pelaksananya. 
Ketiga, Pasal 75 tentang Pembinaan dan Pasal 76 tentang Pengawasan juga berpotensi sebagai pasal karet karena tidak mengelaborasi mengenai bentuk pembinaan dan pengawasan apa yang seharusnya dilakukan untuk memastikan terselenggaranya tata kelola perlindungan buruh migran Indonesia. Ini juga berpotensi menimbulkan konflik kelembagaan terkait kewenangan dan tanggungjawab pembinaan dan pengawasan.

Keempat, kelemahan lain yang terkandung dalam undang-undang ini adalah belum adanya pasal khusus yang mengafirmasi kebutuhan khusus perlindungan buruh migran Indonesia (terutama perempuan) yang bekerja di sektor pekerja rumah tangga. Kebutuhan ini penting mengingat mayoritas buruh migran Indonesia bekerja di sektor ini dan menghadapi situasi kerentanan yang berkepanjangan. Tentu saja hadirnya undang-undang Pelindungan Pekerja Migran Indonesia tentu bukan jawaban satu-satunya atas tuntutan kehadiran negara dalam perlindungan buruh migran Indonesia tetapi harus disertai dengan langkah-langkah konkrit mencabut kebijakan-kebijakan lama yang sudah usang dan menyegerakan adanya transisi perubahan tata kelola migrasi tenaga kerja yang berbasis pada tanggungjawab negara atas perlindungan warganya dan penghormatan atas hak asasi manusia serta keadilan dan kesetaraan gender.

Pemerintah Indonesia harus didesak untuk memastikan undang-undang Pelindungan Pekerja Migran Indonesia tidak dibajak oleh kepentingan-kepentingan anti buruh migran yang memanfaatkan potensi kelemahan-kelemahan yang masih terkandung didalam undang-undang tersebut. Untuk menutupi kelemahan undang-undang Pelindungan yang belum memberi perhatian khusus pada pekerja rumah tangga migran maka DPR-RI dan Pemerintah Indonesia harus segera meratifikasi Konvensi ILO 189 dan menuntaskan legislasi RUU Perlindungan Pekerja Rumah Tangga untuk memastikan terselenggaranya perlindungan terhadap buruh migran Indonesia yang bekerja di sektor pekerja rumah tangga.

Kelima, peraturan mengenai bantuan hukum bagi calon PMI atau PMI tidak diatur secara rinci, dimana pada prinsipnya UU PPMI mengakui hak bagi calon PMI atau PMI hal ini tercantum dalam Pasal 6, yaitu:

(1) Setiap Calon Pekerja Migran Indonesia atau Pekerja Migran Indonesia memiliki hak:

a. mendapatkan pekerjaan di luar negeri dan memilih pekerjaan sesuai dengan kompetensinya;

b. memperoleh akses peningkatan kapasitas diri melalui pendidikan dan pelatihan kerja;

c. memperoleh informasi yang benar mengenai pasar kerja, tata cara penempatan, dan kondisi kerja di luar negeri;

d. memperoleh pelayanan yang profesional dan manusiawi serta perlakuan tanpa diskriminasi pada saat sebelum bekerja, selama bekerja, dan setelah bekerja;

e. menjalankan ibadah sesuai dengan agama dan keyakinan yang dianut;

f. memperoleh upah sesuai dengan standar upah yang berlaku di negara tujuan penempatan dan/atau kesepakatan kedua negara dan/atau Perjanjian Kerja;

g. memperoleh pelindungan dan bantuan hukum atas tindakan yang dapat merendahkan harkat dan martabat sesuai dengan ketentuan peraturan perundang-undangan di Indonesia dan dinegara tujuan penempatan;

h. memperoleh penjelasan mengenai hak dan kewajiban sebagaimana tertuang dalam Perjanjian Kerja;

i. memperoleh akses berkomunikasi;

j. menguasai dokumen perjalanan selama bekerja;

k. berserikat dan berkumpul di negara tujuan penempatan sesuai dengan ketentuan peraturan perundangundangan yang berlaku di negara tujuan penempatan;

1. memperoleh jaminan pelindungan keselamatan dan keamanan kepulangan Pekerja Migran Indonesia ke daerah asal; dan/atau

m. memperoleh dokumen dan Perjanjian Kerja Calon Pekerja Migran Indonesia dan/atau Pekerja Migran Indonesia.

Dimana pada prinsipnya UU PPMI mengakui hak untuk memperoleh perlindungan dan bantuan hukum bagi calon PMI atau PMI hal ini tercantum dalam Pasal 6 huruf (g), menyatakan:

"Setiap calon pekerja migran Indonesia atau pekerja migrant Indonesi memiliki hak:. memperoleh pelindungan dan bantuan hukum atas tindakan yang dapat merendahkan harkat dan martabat sesuai dengan peraturan perundang-undangan di Indonesia dan di negara tujuan penempatan"

Disaat PMI bekerja di negara penempatan UU PPMI pun memberikan hak bagi PMI untuk mendapatkan pendampingan, mediasi, advokasi dan pemberian bantuan hukum berupa fasilitas jasa advokat oleh Pemerintah Pusat dan/atau Perwakilan Republik Indonesia. Sebenarnya UU PPMI memandatkan adanya perlindungan hukum bagi PMI yang diatur secara khusus pada BAB VII UU PPMI, namun hal tersebut hanyalah sebatas gambaran umum saja, tidak dijelaskan tersendiri bantuan hukum seperti apa yang berhak didapatkan oleh PMI jika terlibat masalah atau kasus. Akses mengenai bantuan hukum pun tidak terintegrasi dengan undang-undang Bantuan Hukum di Indonesia yaitu Undang-Undang No 16 tahun 2011, dimana 
disebutkan bahwa negara bertanggung jawab untuk memberikan bantuan hukum bagi setiap warga negaranya (Oki Wiratama, $2018: 35$ )

Selain itu UU PPMI memberikan peluang besar kepada PMI untuk tunduk pada peraturan perundangundangan negara tujuan penempatan, serta hukum dan kebiasaan internasional. Permasalahannya adalah sejak awal PMI tidak dibekali pengetahuan yang rinci mengenai hukum yang berlaku di negara penempatan dan tidak dibekali dengan buku panduan khusus untuk bekerja di negara tertentu.

Dalam UU PPMI belum diatur mengenai mekanisme khsusus PMI mendapatkan keadilan, misalnya gambaran umum menempuh jalur perdata terhadap PPTKIS yang melakukan pelanggaran maupun mekanisme pidana yang dapat ditempuh. Hanya saja baru diatur secara umum mengenai penyelesaian perselisihan dengan cara musyawarah, melalui Dinas Tenaga Kerja setempat, hingga gugatan ke pengadilan.

Indonesia sendiri sudah memiliki Peraturan Mahkamah Agung No 2 tahun 2015 Tentang Tata Cara Penyelesaian Gugatan Sederhana (Small Claim Court). Hal ini dapat dilakukan oleh PMI yang dirugikan oleh perusahaan penyedia jasa tenaga kerja untuk menggugat sederhana ke pengadilan negeri setempat.

Small Claim Court tersebut, haruslah dengan objek perkara yang nilainya dibawah Dua Ratus Juta Rupiah, dan hanya bisa untuk perkara wanprestasi dan perbuatan melawan hukum (PMH) serta pihak penggugat tidak boleh lebih dari satu orang kecuali memiliki kepentingan yang sama. Namun Perma No 2 Tahun 2015 ini, hanya dapat digunakan apabila penggugat dan tergugat berdomisili di wilayah pengadilan yang sama.

Hal-hal seperti ini belum diketahui oleh para PMI, pemerintah maupun pendampingan pekerja migran, padahal ini merupakan peluang untuk mengakses dan memperoleh keadilan bagi PMI disamping hanya menempuh proses pidana saja.

UU PPMI pun mengatur mengenai sanksi bagi PPTKIS yang menyalahi prosedur berupa: tidak menempatkan PMI sesuai dengan jabatan dan jenis pekerjaan yang tercantum dalam perjanjian kerja, tidak melaporkan data kepulangan PMI, tidak bertanggung jawab terhadap perlindungan pekerjanya yang ditempatkan di luar negeri.

Dalam UU PPMI disebutkan berbagai macam jenis sanksi administratif yang berupa peringatan tertulis, penghentian sementara sebagaian atau seluruh kegiatan usaha dan pencabutan izin. Pemberian sanksi administratif ini sering menempuh birokrasi yang sulit dan rumit dari petugas pengawas ketenagakerjaan untuk segera menerbitkan nota pemeriksaan sebagaimana diatur di dalam Peraturan Menteri Tenaga Kerja Nomor 33 Tahun 2016 tentang Tata Cara Pengawasan Ketenagakerjaan.

Apabila dibandingkan dengan UU No 39 tahun 2004, bantuan hukum diatur hanya pada 1 pasal yaitu pasal 80, yang berbunyi:

a. Pemberian bantuan hukum sesuai dengan ketentuan peraturan perundang-undangan di Negara tujuan serta hukum dan kebiasaan internasional

b. Pembelaan atas pemenuhan hak-hak sesuai dengan perjanjian kerja dan/atau peraturan perundangundangan di negara TKI ditempatkan

Hingga UU No 39 tahun 2004 berlaku belum ada PP khusus yang mengatur mengenai bantuan hukum bagi pekerja migran. Sedangkan dalam Pasal 17 dan 20 PP No 3 Tahun 2013 Tentang Perlindungan Tenaga Kerja Indonesia di Luar Negeri, meskipun telah disebutkan mengenai perlindungan namun tidak secara tegas mengatur mengenai teknis pemberian bantuan hukum, misalnya mekanisme mengakses bantuan hukum pengadilan mana yang berwenang dan mekanisme restitusi bagi pekerja migrant (Oki Wiratama, 2018 : 35).

Selain itu kewenangan memberikan bantuan hukum didalam PP No 3 Tahun 2013 menjadi tugas PPTKIS pada masa penempatan. Hal tersebut sangatlah bersiko apabila PPTKIS diberikan wewenangan memberikan bantuan hukum, dikarenakan pelakunya terkadang dari PPTKIS itu sendiri, dan tugas bantuan hukum seharusnya negaralah yang memberikannya kepada warga negara khususnya PMI. Berbeda dengan UU PPMI, dimana tidak ada kewenangan PPTKIS dalam memberikan bantuan hukum, namun dalam UU PPMI tersebut hingga kini belum ada PP khusus mengatur mengenai mekanisme bantuan hukum bagi PMI.

\section{SIMPULAN DAN SARAN}

\section{Simpulan}

Sejak disahkannya Undang-Undang No 18 Tahun 2017 tentang Pelindungan Pekerja Migran Indonesia, ada istilah baru pengganti Tenaga Kerja Indonesia (TKI) menjadi Pekerja Migran Indonesia (PMI). Semangat dari Undang-Undang No 18 tahun 2017 sebagaimana dituangkan dalam penjelasan umum adalah agar PMI terlindungi dari perdagangan manusia, termasuk perbudakan dan kerja paksa, korban kekerasan, 
kesewenang-wenangan, kejahatan atas harkat dan martabat manusia, serta perlakuan lain yang melanggar hak asasi manusia. Selain itu, undang-undang tersebut lebih menekankan dan memberikan peran yang lebih besar kepada pemerintah dan mengurangi peran swasta dalam penempatan dan Perlindungan Pekerja Migran Indonesia. Dalam undang-undang No 18 tahun 2017 ini, sudah ada regulasi yang lebih baik dan dapat menjadikan patokan untuk menjadikan TKI/PMI kita lebih memiliki nilai bargaining position yang jelas sesuai dengan skill dan kompetensi yang dimiliki oleh masing-masing TKI/PMI.

Pada kenyataannya, undang-undang ini juga masih menyimpan beberapa kelemahan,diantaranya:

a. ketidak konsisten dalam menerapkan aturan. Dimana dalam satu sisi disebutkan pelaksanaan penempatan PMI terdiri atas 3 pelaksana yaitu badan, perusahaan swasta dan mandiri, namun di sisi lain terutama tentang perjanjian penempatan PMI yang merupakan salah satu dari dokumen wajib yang dimiliki oleh calon PMI. Dimana mengenai dokumen tersebut hanya melalui perusahaan swasta saja,

b. UU PPMI masih menyimpan potensi konflik kelembagaan mengenai kewenangan Kementerian dan Institusi/Badan Non Kementerian dalam tata kelola perlindungan buruh migran.

c. Pasal-pasal didalam UU PPMI mengenai pembinaan dan pengawasan juga berpotensi sebagai pasal karet karena tidak mengelaborasi mengenai bentuk pembinaan dan pengawasan apa yang seharusnya dilakukan untuk memastikan terselenggaranya tata kelola perlindungan buruh migran Indonesia.

d. belum adanya pasal khusus yang mengafirmasi kebutuhan khusus perlindungan buruh migran Indonesia (terutama perempuan) yang bekerja di sektor pekerja rumah tangga.

e. Peraturan mengenai bantuan hukum bagi PMI tidak diatur secara rinci.

\section{Saran}

Segera merevisi Undang-Undang Pelindungan Pekerja Migrant Indonesia, kemudian harus dikawal dan dituntaskan 27 (dua pulu tujuh) peraturan turunan mandat dari UU PPMI yang terdiri dari 12 (dua belas) Peraturan Pemerintah (PP), 11 (sebelas) peraturan setingkat Menteri (Permen), 3 (tiga) peraturan Badan dan 1 (satu) Peraturan Presiden (Perpres).

\section{DAFTAR PUSTAKA}

Amiruddin \& Zainal Asikin, 2003. Pengantar Metode Penelitian Hukum. PT Raja Grafindo: Jakarta

Hani Adhani, Undang-Undang Pelindungan Pekerja Migran Indonesia, https://www.hukumonline.com/berita/baca/lt5acaed204a40c/melindungi-pekerja-migran-indonesiaoleh-hani-adhani, diakses pada tanggal 1 Maret 2019

http://bnp2tki.go.id

https://news.detik.com/berita/d-3661292/sepanjang-2017-ada-148285-tki-ditempatkan-di-luar-negeri, diakses pada tanggal 28 april 2019.

Oki Wiratama. 2018. Buku Saku Memahami Undang-Undang Pelindungan Pekerja Migran Indonesia. Jaringan Buruh Migran: Jakarta.

Wahyu Sosilo, Membaca Kritis Undang-Undang Pelindungan Pekerja Migran Indonesia, (https://www.dw.com/id/membaca-kritis-uu-pelindungan-pekerja-migran-indonesia/a-41595460, diakses pada Tanggal 1 Maret 2019

\section{Peraturan Perundang-Undangan}

Undang-Undang Dasar Negara Kesatuan Republik Indonesia Tahun 1945.

Indonesia, Undang-Undang No. 39 tahun 2004 tentang Penempatan dan Perlindungan Tenaga Kerja Indonesia di Luar Negeri, LN Republik Indonesia Tahun 2004 No. 133.

Indonesia, Undang-Undang No 18 Tahun 2017 Tentang Pelindungan Pekerja Migran Indonesia, Tambahan Lembar Negara RI Nomor 6141.

Indonesia. Undang-Undang No 16 tahun 2011 Tentang Bantuan hukum di Indonesia

Peraturan Pemerintah No 3 Tahun 2013 Tentang Perlindungan Tenaga Kerja Indonesia di Luar Negeri

Peraturan Mahkamah Agung No 2 tahun 2015 Tentang Tata Cara Penyelesaian Gugatan Sederhana (Small Claim Court) 